\title{
Fostering indigenous entrepreneurship amongst San people: an exploratory case of Tsumkwe
}

\section{Wilfred Isak April*}

University of Namibia, Private Bag 13301, Windhoek, Namibia

Email: drwilfredisakapril@gmail.com

*Corresponding author

\section{Daniel lleni Itenge}

\author{
Maltas Club Namibia, \\ P.O. Box 279191, Windhoek, Namibia \\ Email: ditenge@gmail.com
}

\begin{abstract}
This paper seeks to explore new ways to foster indigenous entrepreneurship amongst the San people. Policies such as the Harambee Prosperity Plan and Vision 2030 were designed to support the developmental agenda of Namibia. This study will follow an ethnographic approach, by making use of in-depth interviews, storytelling and participant observation. Combining the Western and African approaches to development is critical when we wish in improving the livelihoods of marginalised communities. Indigenous entrepreneurship is one way through which the San people can be empowered, as it has both economic and non-economic objectives. Improving the entrepreneurial propensity of the San people is important as it can aid in the development of the local communities and the overall growth of the national economy. This paper is one of the important studies in the context of indigenous entrepreneurship in Namibia. Studies with reference to indigenous entrepreneurship in terms of the San people of Tsumkwe are very few or nonexistent in Namibia.
\end{abstract}

Keywords: indigenous entrepreneurship; entrepreneurial culture; Namibia; Tsumkwe.

Reference to this paper should be made as follows: April, W.I. and Itenge, D.I. (2020) 'Fostering indigenous entrepreneurship amongst San people: an exploratory case of Tsumkwe', Int. J. Business and Globalisation, Vol. 24, No. 4, pp.496-512.

Biographical notes: Wilfred Isak April is a Generation Y Scholar and has a strong passion for community development, entrepreneurship and indigenous people. He holds an undergraduate Business degree from the University of Namibia. In 2003, he obtained double honours in BComm (Industrial Psychology and Human Resource Development from the University of Stellenbosch. He is also a Master's of Commerce (Business Management) graduate from the Stellenbosch University in collaboration with the European Business School in Germany. He received his PHD in Entrepreneurship from New Zealand and intends to pursue a second Master of Law (Intellectual Property) followed a second doctorate in the near future. He is the Founder of Maltas Club Namibia, which aims at developing the entrepreneurial potential of young students at all universities in Namibia. 
Daniel Itenge holds a Degree in Business Administration (University of Namibia) and MSc in Labour Economics (University of Turin). He is a highly ambitious young man with keen interests in leadership, management, and entrepreneurship. Through his work and the roles he play in his community, he has gained a deeper insight into the real pressing issues in his community, and recognises the need for exceptional leaders to steer their communities in the most prosperous direction, as he believes that 'leadership is action, not position'. He is serving as a Senior Employment Officer at Ministry of Labour.

\section{Introduction}

According to Hindle and Lansdowne (2005) Canada has justifiably been acclaimed as the world's most advanced state in policy making, enterprise development and research when it comes to the field of indigenous entrepreneurship. Given the fact that the world's first $\mathrm{PhD}$ in the field of indigenous entrepreneurship was completed by Canadian Leo Paul Dana, Canada has made major breakthroughs to the field of indigenous entrepreneurship. Dana (1995) reiterates the fact that people do not become self-employed for the same reasons.

Numerous investors from abroad have invested billions of dollars into the African continent during the past two decades, and certainly there is more hope than despair for Africa. In Namibia, investments have been made, but putting in appropriate and healthy strategic interventionist policies, as was discussed by Dana (1993) remains a major challenge. The long dream of developing an enterprise culture in empowering the less privileged such as the San people has not materialised. This is partly due to corruption, nepotism, greed and dishonesty which have rigged the Namibian nation.

Policy makers, economic and community planners are constantly seeking new ways to write an integrated and well developed plan giving a clear reflection of the nation. An entrepreneurial culture is fostered and seen as different in Namibia as each tribe views entrepreneurship differently. The view on values and beliefs on entrepreneurship is influenced by tradition and the manner within which entrepreneurship is viewed from a cultural vantage point in Namibia.

Whilst this subjugation of the improvement in the livelihoods of other ethnic groups/tribes has occurred in Namibia, what went wrong with the San people? Why has there been no significant improvement in their livelihoods, in particular the youth? Or is developing their full entrepreneurial potential seen as another problem or hindrance? Why have the Namibian government not make a conscious deliberate effort to invest in these people (including SMEs compete, which receives funding and donations from the government).

According to Dana (2015) it is important to note that there is heterogeneity amongst indigenous people. Even within one geographic area, there exist differences amongst unlike indigenous people. For instance the Mina people came to dominate to the exclusion of northern tribes, along the western coast of Africa. They were treated as savages and excluded from significant positions. Back here in Namibia, the San people are treated like strangers in their own land, with no noteworthy positions in leadership and a voice for their own people. 
The San people of Tsumkwe are ready for both social and economic change. Although their values and customs are deeply rooted in their culture the San people are constantly seeking new ways of achieving self-determination. To some it appears that the government is not doing enough, and this can be very devastating as the San people might develop a victim mentality. Very few writings in the academia sees the potential advantages that indigenous entrepreneurship can bring in terms of development for Namibia, as was explored in this paper. The primary objective of this paper was to explore how the Namibian San people can be empowered through indigenous entrepreneurship.

First the paper will sensitise the readers with the background of the San people and the Village of Tsumkwe. Thereafter the paper broaches into the literature of indigenous entrepreneurship and the role culture can contribute actively to the Namibian economy, given their unique skills and talents. Without a doubt if Namibia wants to become a global player, which wish to achieve all its' visions, plans and Agenda 2053; there is a need to understand the discourse of integrating all ethnic groups on an equal playing field. It is critical that the San people no more live in isolation - and become an integral part and parcel of the development of Namibia.

Namibia needs alternative programs to strengthen and build the major milestones in ensuring positive outcomes for the San people who wish to play an active role in the national economy. In depth interviews, personal life stories and participant observation will be used to support the research methodology of this paper. Finally, conclusions and recommendations for further research are outlined.

\section{Background of the San people}

The San people across Southern Africa have been living for about 20,000 years. In addition this paper is not based on all San people across all Southern Africa. This paper makes reference to the people of Tsumkwe. Pejoratively the San were also called Bushmen, or the people of the 'bush'. They are an indigenous group of people mostly found in Southern Africa. They are also closely related in terms of the physical facial features and the click $(! / /, \#, /)$ language similar to the Nama people in Namibia (April et al., 2017).

Why is indigenous entrepreneurship so essential for the development of the San people? From an 'indigenous entrepreneurship' stance it is the desire of any indigenous person or persons 'to become 'self-reliant' and socially cohesive'. San people are more than it meets the eye; they possess unique qualities, wisdom and spiritual intellect which might not necessarily be acquired through formalised education. The village of Tsumkwe does not only constitute San people as was in the earlier days. There is an influx of other tribes from all across Namibia. The local inhabitants need to teach the visitors differently. They can achieve this by staying steadfast in the manner within which they do things and view the world. International and local visitors must see the world from that of the San perspective. When these two different ways of thinking meet, it can certainly be a formidable combination. What makes the village of Tsumkwe so special? Location is everything when we look at Tsumkwe. Situated 250 kilometres from Grootfontein this village has unique opportunities in terms of cultural exchange. Furthermore the opportunities for indigenous entrepreneurship are limitless. From the author's vantage point, people see development as a quick fix where all of a sudden communities have to 
be empowered with electricity, big houses and cars. That is not true development. Development should first start from within the people and how they gradually wish to be integrated and empowered in the process.

There are two schools in the village; namely the Tsumkwe primary and secondary schools. Most learners attending these schools are from the villages within the Tsumkwe district. Very few come from other regions across Namibia. The livelihood of most communities are hunting and gathering. There is a small petrol station approximately 600 meters from the school, and 100 meters down the road is a small community library. The village also has a small shop where one can purchase traditional necklaces and other traditional items. It is the thesis of this paper that what is viewed as uniquely San should under no circumstances be viewed as backward, as it is at times our own making as indigenous people that we fail to take pride in our own customs and traditions. The West must meet Africa, in creating a better world, where Africans; can step up in power and defend this continent. What one believe as uniquely San can give one the zeal and confidence for life which can easily make room to spot unique opportunities in the market? This is an essential quality for the advancement and prosperity of the San people. The next section of this paper will review the related literature on indigenous entrepreneurship and culture.

\section{Indigenous entrepreneurship and culture}

This paper will discuss indigenous entrepreneurship in terms of the international perspective and that of the San perspective in Namibia.

\subsection{International literature}

Entrepreneurship originates from a French verb (entreprendre), which basically means 'to undertake' (Desai, 1999). In simple terms to take ones bare hands and do something. The question is then how do people take their hands and do something? We do this by interacting with our own families, communities and society at large. Furthermore we extend our services by doing business in the community. In terms of the San people going out to the field on a daily basis and hunting wildlife, to put food on the table for family. At times it could be simple things such as counting the livestock in the kraal. Each of these people we interact with has their own cultural values and beliefs. According to Schumpeter (1934) in Dana (1996) entrepreneurial activity is to do things which were already done, but in new innovative combinations, for example the introduction of a new good, the introduction of a new method of production; the opening of a new market; the conquest of a new source of supply of a raw material and the carrying out of a new organisation in an industry.

This brings us to the definition of 'indigenous entrepreneurship' as was defined by Peredo et al. (2004, p.3) which has the view that this is an entrepreneurial process of an enterprise that encompass the desire of an Indigenous person or persons to become self-reliant and socially cohesive. This definition should by no means be seen as a condition that is only applicable in today's contemporary times, but amongst some indigenous groups such as those in Canada and Australia which dates back to some 8,000 
years ago. It will be noteworthy also to mention that this was even long before the birth of Christianity.

However, it is important to reiterate the impacts that indigenous entrepreneurship could have on their communities is not known, as the indigenous people did not have the chance to write down their own stories and experiences they deemed as entrepreneurial. If we look at the current knowledge of indigenous entrepreneurship to the academic fraternity and the public at large not much has been written on this topic till date. Therefore, experiments such as this one based on the indigenous entrepreneurship of San people, one of the oldest inhabitants in Namibia, with no literacy or very few resources is timely. It is important that these communities tell their own stories to the world in terms of how they view economic development and prosperity, while remaining intact with their unique culture.

A ground-breaking study by Dana (2007) conducted in the West African nations of Ghana and Togo noted that regardless of the entrepreneurial initiatives one brings to a particular community, the challenges of a lack of literacy, lack of managerial skills, lack of technology, lack of access to technology, lack of capital and poor infrastructure makes the sustainability of businesses a challenge. In addition, a lack of telecommunication services (telephones), excessive regulations and in particular ethics affect the ability to do business efficiently. These factors damper the entrepreneurial drive and spirit of the communities. The current situation in Tsumkwe is no different.

Another form of entrepreneurial activity which can be practiced by indigenous people is self-subsistence form of employment, where communities can gather food and resources for personal use. This usually includes hunting/ fishing. In the case of the Tsumkwe people on which this paper is based hunting is the most prevalent one. This can either be fulltime or part-time. One can also talk of the legitimate informal economy where there is an uncontrolled exchange of goods and services in the absence of an official enterprise. Self-employment in the formal sector takes the form of official, legal enterprise profits of which are usually declared by government authorities (Dana, 1996). For example a dentist is officially self-employed.

Namibia is rich in 'cultural diversity', with close to 13 ethnic cultural groups, from which the San people are the most marginalised. If we look at this issue more at a policy level or top governmental positions, this group of people also appears not to be fully represented. Most individuals which speak for the San people are seasonal visitors to Tsumkwe or often those who are non-indigenous. These people generally do not make a case or argument for indigenous entrepreneurship, and how the communities can achieve self-determination and self-reliance. The challenge furthermore is that our own people do not see this, be it a mere act of ignorance or we simply do not want to see it. According to the seminal paper of Barnes (2000) the practice of speaking for another cultural group, whether it is through pictures, recordings or writings, is a highly debatably act. Although the intentions are good, the amount of distortions which could occur left a lot to be desired.

Empowering the Namibian San people through indigenous entrepreneurship should not be seen as a quick fix solution, but it is indeed a process through which these communities can achieve economic independence. This should not be an endeavour whereby welfare mind-sets are promoted. Indigenous people or black Namibians who serves on various developmental boards should not forget where they came from, and not become invisible to the policy makers. Most individuals serving on these boards in Namibia are coming from rural villages similar to that of Tsumkwe, but yet forget why 
and how they escaped that welfare rut in the past. It is time that those that went ahead and succeed in urban communities find new ways and measures to empower those which are left behind in the villages, in ensuring that the intangible cultural heritage of our people are never destroyed. The next section of this paper will look at indigenous entrepreneurial activities in terms of the San people.

\subsection{Namibian San entrepreneurial initiatives}

The level of literacy in a particular economy can also determine the level of entrepreneurial success. Dana (1993) indicated that Namibia appeared to be doing very well in terms of people with literacy and numeracy skills despite the fact that it was one of the last African colonies to gain independence. The overall Namibian economy is dependent on uranium, diamonds, silver, tin, zinc. Most of the people are employed in the agricultural sector. Today this is evident amongst the San people who depend also on food from the field or the bushes. Communities in the agricultural sector appear to have very strong sense of sharing, irrespective of the resources they produce.

Most of the entrepreneurial activity conducted by indigenous people does not take place in the markets of the modern economy. These communities operate in the Bazaar, which is based on the traditional model. These transactions usually occur outside the mainstream markets of the global economy. Exchange is not only determined by the presence of market transactions. Communities can also create their own wealth through kinship ties (Dana, 2015).

Bhensdadia and Dana (2004) put an argument forth that globalisation has both debits and credits: large potential advantages, for instance accelerated growth in Namibia, but the real danger is that the rural poor such as the Namibian San will always be left out. For instance their access to knowledge and other resources in the commercial sector are minimal.

It is important to mention that the gross domestic product (GDP) growth in Namibia is very volatile, because of the heavy reliance of mineral exports, but nevertheless remains robust as this small economy of only over two million people has exceeded many neighbouring countries. The manufacturing sector of the Namibian economy is subdivided in clothing, retail, apparel, hardware and fast moving goods. Seven years ago a major clothing manufacturing giant known as Dinapama Manufacturing and Supplies opened its doors to act as a catalyst for economic growth and development. In addition communities who are eager to start up their own enterprises mainly operate under the Namibian SMEs Compete body. However, due to the scarcity of resources and limited access to proper networks and information, underground economic activities are still prevalent.

Entrepreneurial initiatives in terms of the San people entail making use of the local resources on a daily basis to maintain a sustainable livelihood. In the Bushes of Tsumkwe as the researcher drives through the lonely road, white as chalk, community' houses seems to be hidden in the bushes, usually made from palm tree leaves of corrugated iron. Everything in the community revolves around the family and the clan. The chief appears to have the most say in the kingdom and serves as the mentor. Church leaders also have prominent roles to play, especially during funerals. Entrepreneurial Initiatives among the San people have been raising goats and in rare instances sheep. Mostly they are hunting animals. Other entrepreneurial activities include: 
- $\quad$ counting of livestock every morning

- looking for those who have not returned from the previous day (were they victims of a Jackal or what might have happened)

- milking of the sheep and goats usually happens in the morning and evening (milk is usually used to eat porridge and drink tea).

In addition the hunting wildlife such as springboks and rabbits also constitutes part of the entrepreneurial activities. This is used as a source of food and the skin is used as a form of clothing, a mat for the house and at times sold to tourist. In the holiday season these chores are usually carried out by the children of the community as they do not have to attend school. This is usually done in honouring the parents for providing them with food while attending school. Some Namibian businesses buy these skins from wildlife to decorate furniture. Due to its location, and the lack of access to Tsumkwe due to gravel roads and poor infrastructure; SME's compete is still not prevalent in Tsumkwe. Been able to grant small loans to the San people and teaching them basic financial and literacy skills can indeed ease the burden of poverty for this community in the near future.

\section{Research methodology}

The paper utilises primary data which have mainly been sourced from in-depth interviews, storytelling and participant observation, which required the authors to travel thrice between Windhoek and Tsumkwe. These methods were adopted mainly, because the literacy levels of the community is not very high. Most participants were only fluent in the San vernacular, which is very close to the Khoe-Khoe language some of the author's first language. The participants used for this paper were locals who are very familiar in the village and are experts in the famous Bushman walks around the villages. On a very cold autumn morning (see Figure 1) the authors joined some community members to take an excursion to put the research methods to a test.

Figure 1 Researchers meet with community members in the forest (see online version for colours)

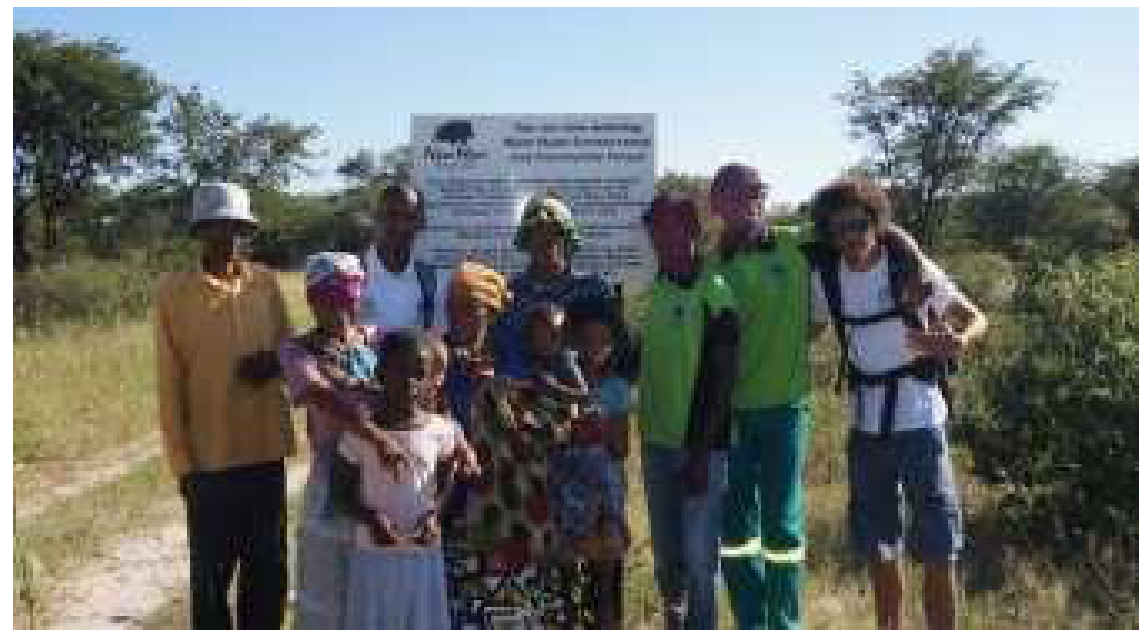


The woman arrived at the meeting point an hour later than the initially agreed time, with a beautiful baby on her back. Some authors could derive meanings from the conversations as they are Nama speaking. This was at times easing the discussion. All methods were used simultaneously as it was easier for the respondents to express their understanding of their culture and values by illustration of their plants and bushes (as will be unpack in Section 6 of this paper) which have kept them going since they were born. These rituals and traditions have been passed on to them from their ancestors.

Let us look briefly at the methods which were used for this paper:

- In depth interviews: These interviews gave the authors repeated face to face encounters with the informants to get a very clear understanding of their perspectives on entrepreneurship and culture. This gave the researchers the opportunity to understand the communities better. With in-depth interviews it is essential that one spent a reasonable amount of time with the informants and this indeed enhanced the rapport, as there was a great opportunity for common understanding and confidence and trust between the parties which lead to detailed and accurate information. This is especially important if we zoom back to the literature on indigenous entrepreneurship, where the non-indigenous people interviews indigenous without having to necessarily spend a great amount of time with them. Most of the information received from informants were reconfirmed and verified.

- Storytelling: Stories are one of the most powerful tools for teaching and obtaining knowledge about a particular group of people (Kumar, 2014). It was almost impossible to conduct effective research without local San people telling their own stories for this research. According to Mbigi (2005) indigenous African cultures transmit their values, ethics and spiritual beliefs through songs, praise, poetry, dances, silent rituals, prayer and storytelling. Stories with great illustrations encourage more commitment, generate more belief and are more memorable, in comparison to quantitative research based on facts. In this paper storytelling gave the informants an opportunity to cleanse their old sorrows and reward all their trials and tribulations by reassuring them that there is hope.

- Participant observation: This is a very useful method in collecting qualitative data (Taylor and Bogdan, 1998). Through participant observation the authors were able to engage in the daily activities of the communities, and also feel, think, and express some of their life experiences. For example eating leaves from a tree or digging deep in the soil to find food or water which are essential requirements for survival. These latter mentioned discussions will be explored in the next section of the paper, which focuses on the discussions and analysis of this research.

\section{Discussions and analysis}

To ensure that the research conducted is supported by the literature and methodology in the previous sections the authors embarked on an exploratory Bushmen walk to derive better meaning and understanding about the people. There are two very critical answers to this research the authors explored through their fieldwork namely:

What is entrepreneurial about the San way of conducting their day to day activities? 
b Explore better measures as to how issues in (a) can support policy and decision makers in Namibia?

In ensuring to find answers to the above questions it was critical that the authors use the following plants and fruit trees in the bush as will be discussed step by step in this section. This will be in the format of how the specific plants or and food trees are used for curing diseases and also at times finding the love of your life.

Before discussing these plant and food trees it was important to have a discussion about culture and entrepreneurship with Susanna Meintjies (not her real name) as to how she views culture and entrepreneurship in their community. She had the following to say:

\begin{abstract}
"Although I am an initial inhabitant from this place and currently employed at the local lodge, I see culture as something which defines me as a San woman. I love our culture and I am also proud to be from this village. I am speaking our own language (San), Afrikaans and English. I have also started to learn the Oshiwambo language as a San person. The purpose for this is that so many diverse cultures visit the lodge and my co-workers are also from Northern Namibia and it is good to teach one another as we are a diverse nation. I do not have a university degree, but hopefully one day I can do that. I do not have a clear understanding of what entrepreneurship entails, but I believe it is business."
\end{abstract}

This brief yet very informative excerpt interview from Susanna gave the researchers hope that going forward people like herself are the ones who will be leaders in the community tomorrow. They could be the primary custodians in guiding policy makers as to what needs to happen in the village without people losing their culture. The Namibian Harambee prosperity plan indeed gives room for the total inclusion of everyone and woman like Susanna who are so passionate about development. Basic entrepreneurship training from organisations such as SMEs compete can help the San people.

Figure 2 is the 'doringtree', its primary purpose is to put its poison at the end of the spear, which is used for hunting purposes. This poison then kills the animal or the living organism targeted. If it is a Springbok or any wildlife, there will be food on the table. If it is an animal which can be of harm to the community, when it dies some of the problems are resolved.

Figure 2 Doringtree used as poison for the hunting spear (see online version for colours)

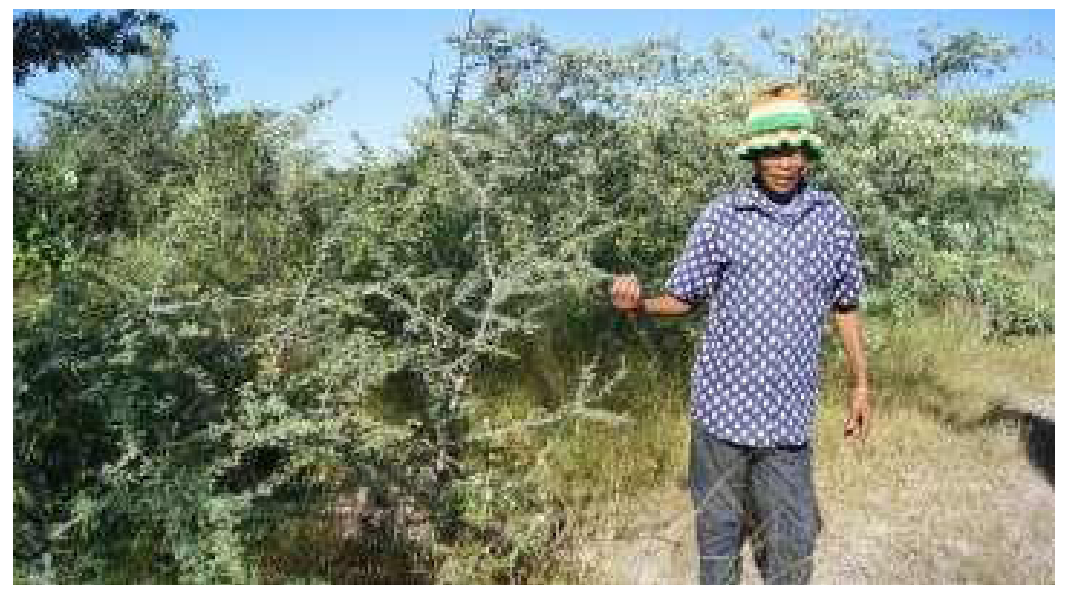


Figure 3 illustrates the footpaths of a springbok in the Bush. The San people have the ability and intuition to identify the animal that crossed the road only by looking at the footprints.

They can also tell with utmost certainty the time the animal cross the road in terms of early morning, late afternoon, evening etc. This also enables them to tell where they can change they path of hunting in case if it is a very dangerous animal which might put their lives at risk.

Figure 3 Illustration of animal or wildlife footpaths (see online version for colours)

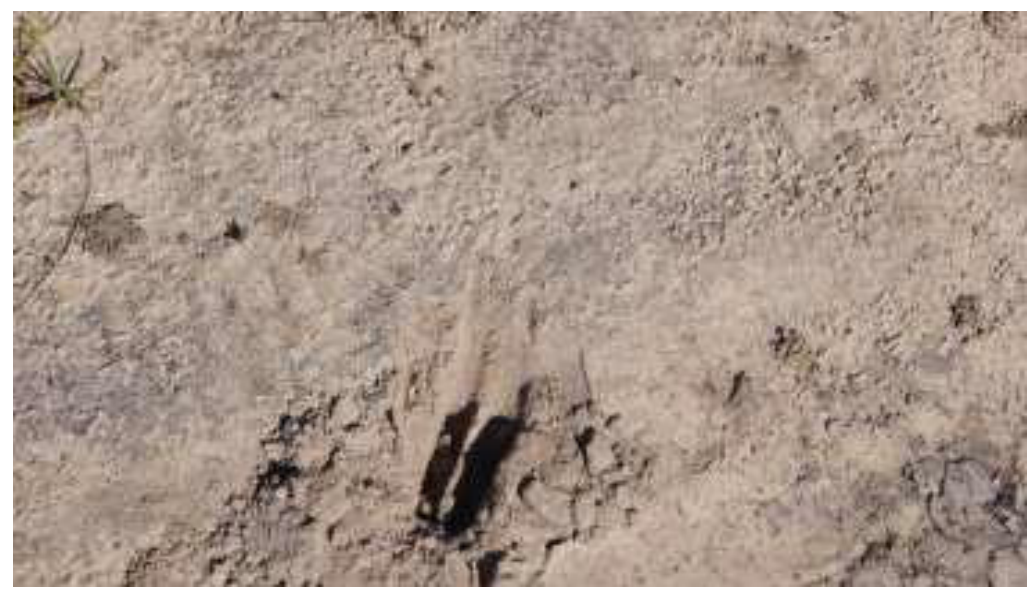

Figure 4 This plant is very healthy according to the interviewee to help with indigestion (see online version for colours)

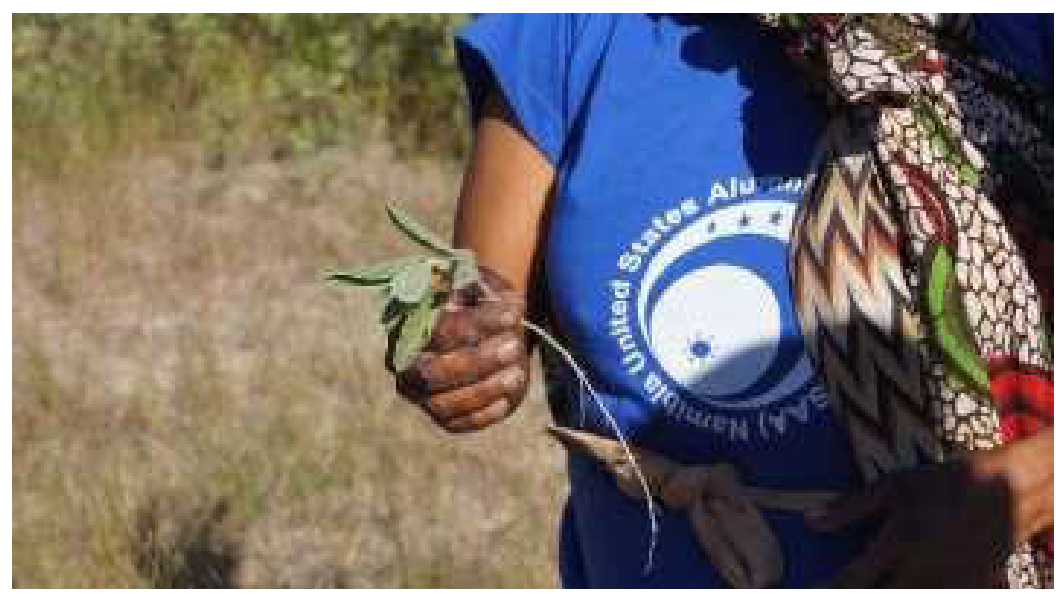

Note: The root of the plant is boiled to 100 degrees and the water is drank to cure with indigestion. 
Figure 5 The bow and arrow is very critical, yet essential in the life of any San person as it is the tool they use to hunt and gather their food (see online version for colours)

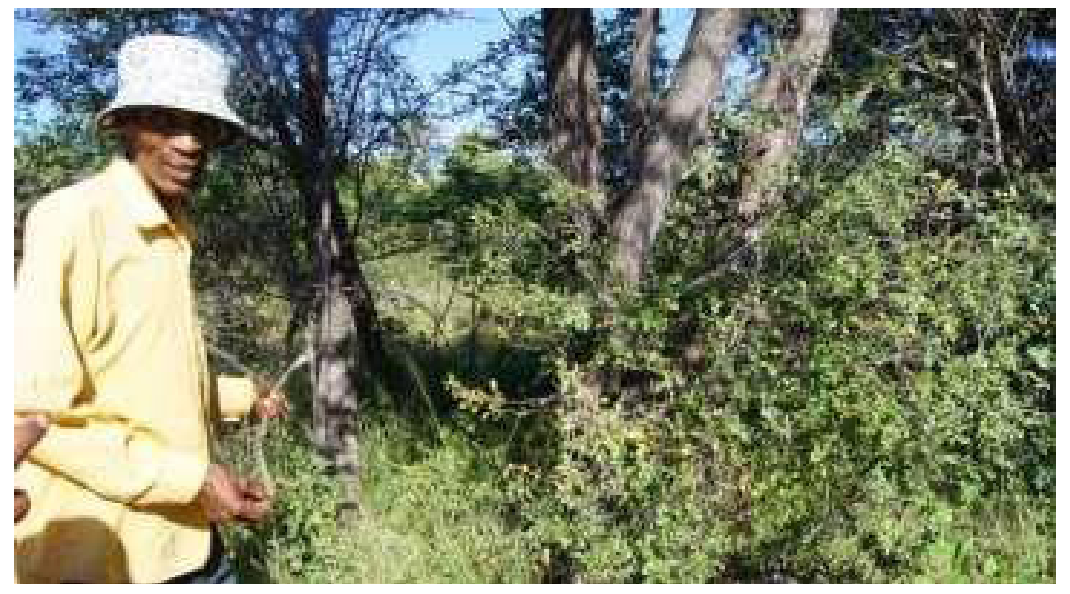

Figure 6 This plant is used as a detox for the body to clean out the entire body of a person (see online version for colours)

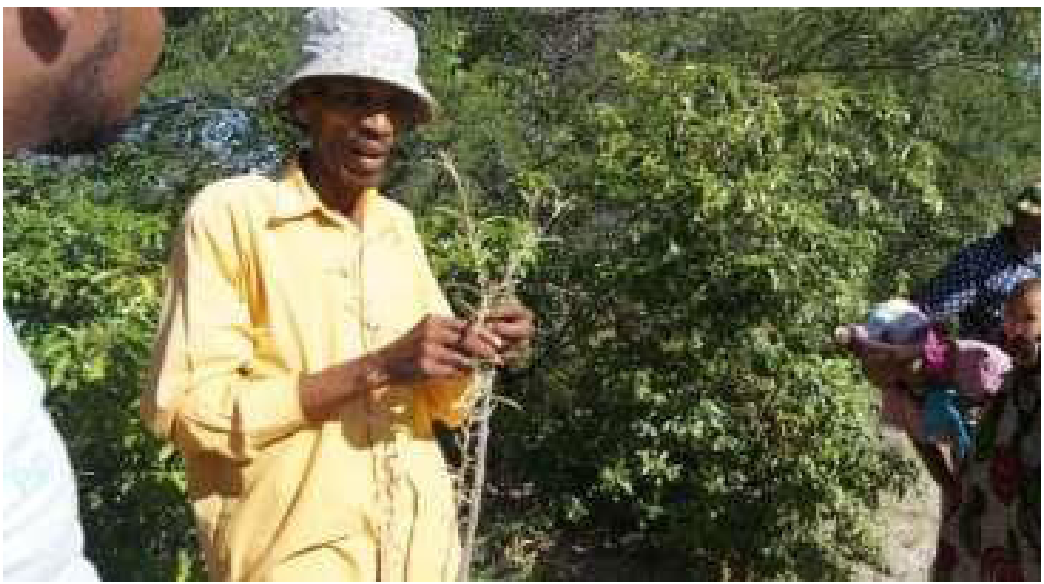


Figure 7 This plant is very important for mothers after having given birth to their little bundles of joy (see online version for colours)

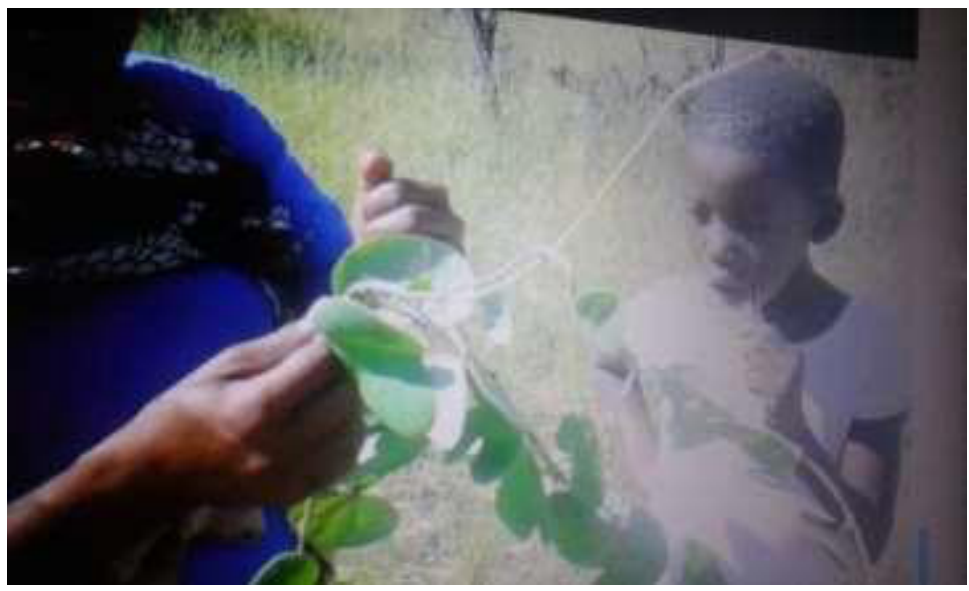

Note: It ensure that all the dirty blood is cleansed out of the body.

Figure 8 The tree below is used for jewellery, which the San people usually sell along the road to tourist visiting Namibia or at time at their traditional jewellery shop opposite the schools in Tsumkwe (see online version for colours)

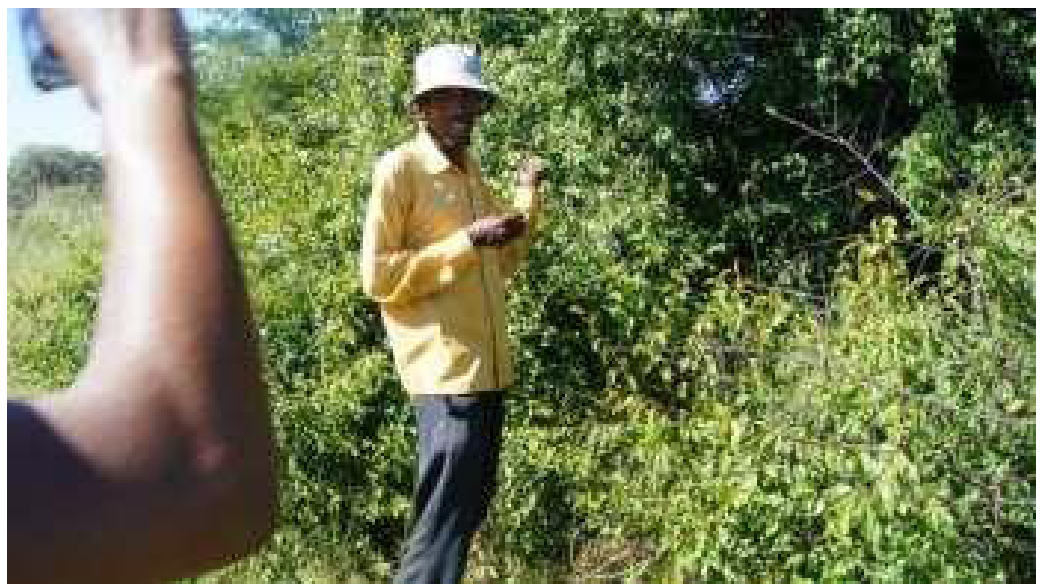

Note: Some of the jewellery they designed are also used for their traditional attire and garments, they used for their traditional dances and performances. 
Figure 9 As was described by the interviewee passionately this plant carries food at certain times (see online version for colours)

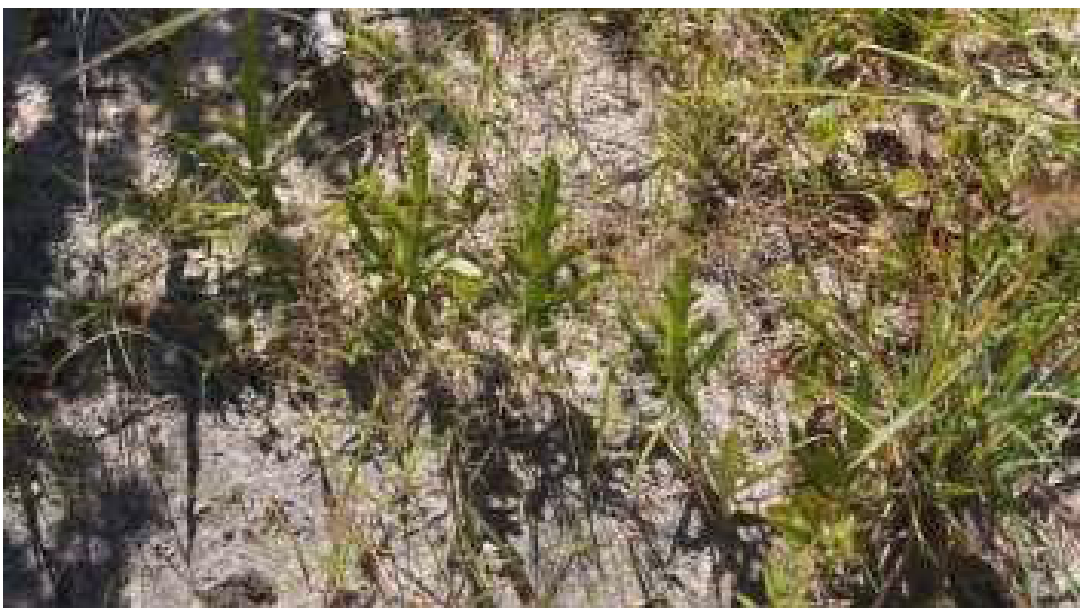

Notes: However this plant is also used for medical purposes when a community member has been bitten by a snake, as it help you to vomit the poison from your body. So it helps in removing the poison from the victim.

Figure 10 This plant is used as love potion by some of the community members (see online version for colours)

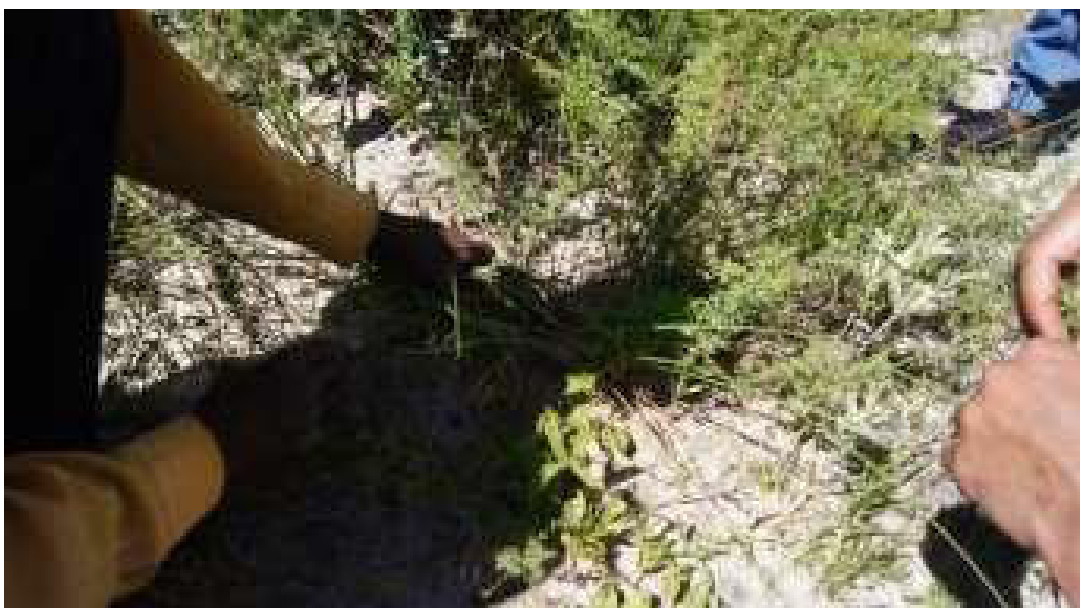

Notes: The plant is usually mixed with tobacco and you can smoke it as an herb with the lady you wish to have a romantic relationship with. It can also be mixed with Vaseline and used as lotion or one can also chew it when you meet with the person you wish to have a romantic relationship with. 
Figure 11 The tree below carries berries, which is usually eaten (see online version for colours)

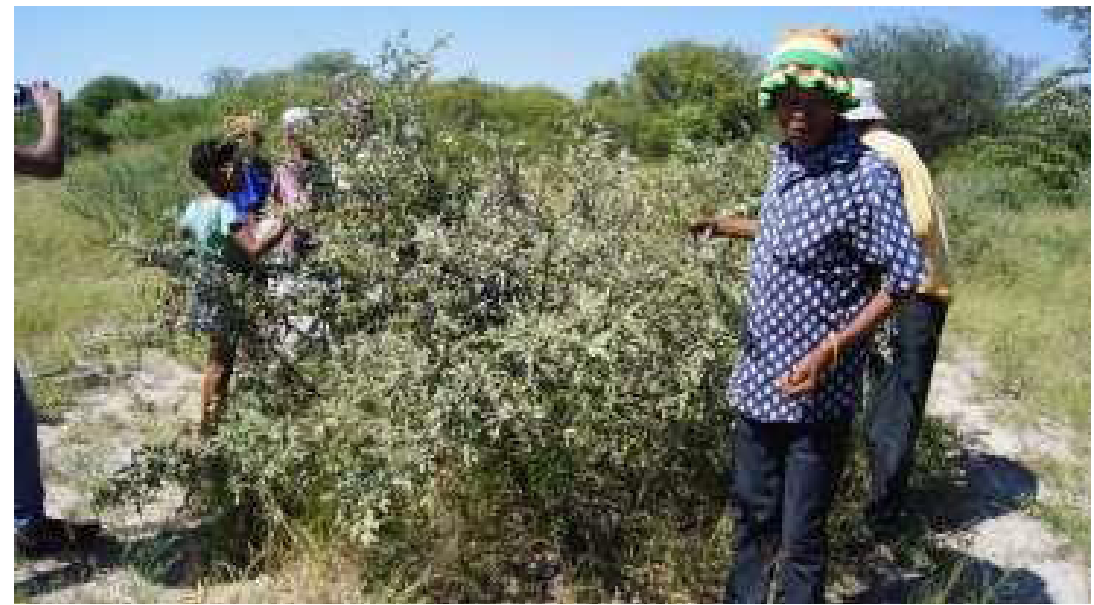

Notes: The Nama (Khoe-Khoe) people from Southern Namibia also eat these berries. This tree shows one of the many things the Nama and San people have in common.

Figure 12 This plant is used to seal the lid of the pot at home, by tying it closed (see online version for colours)

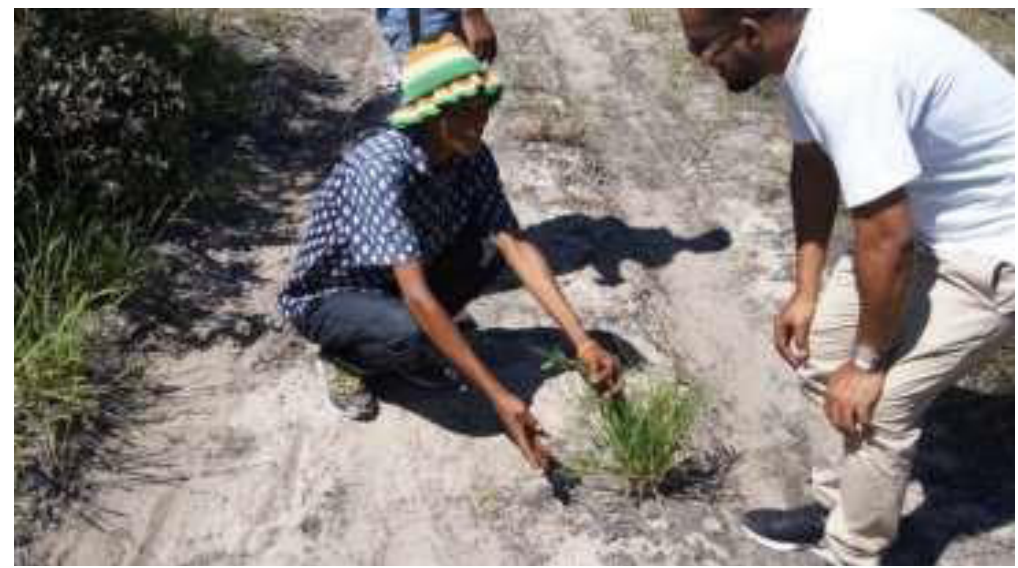

Notes: Any one going to the veld can use this plant as a precautionary measure. When sealed with this plant the pot will remain on the fire and no family member home will want to dish the food as long as the one which ties it remains in the veld.

Looking closely at some of the plants and medicine used by the San people the authors can argue that there is indeed an entrepreneurial venture and culture in Tsumkwe. If we look at the initial definition of entrepreneurship which is derived from a French verb 'entreprendre', which means to take ones hand and do something. For example if we look at the plant in Figure 2 the spear is a very important object the San people need for hunting, as the wildlife or animals they kill enables them to put food for their families and communities. 
Looking at the first research question we wish to answer through this research as to how the entrepreneurial culture of the San people can be fostered? It is clear that the San people are very proud of their culture, as is discussed with Susanna Meintjies in a brief interview in the discussions above as to how she used her culture to make a living for herself and how she works with people of different nationalities at the Tsumkwe lodge. Ms. Meintjies believes that although she does not possess a university degree one day she might be able to achieve this noble and ambitious dream. With additional support and a formal education and literacy skills, Ms. Meintjies will be able to do phenomenal things in the Tsumkwe village.

If we look closely at Figure 3, it is clear that the communities have a strong entrepreneurial intuition, as they are able to tell what kind of animals are crossing a particular road in the Bush. In addition they do not only identify the kind or type of animal they can tell the exact time whether it is morning, midday or late afternoon. The San people indeed use their experiences and cultural rituals from the old age to tell exactly as to how they will deal with a particular situation. A strong entrepreneurial culture is also evident from Figures 4 and 7. In Figure 4 they are boiling the roots of the plants to cure indigestion, so no need for them to use money to acquire resources while they can use the local resources from the veld. In addition in Figure 7, the plant which is used by women when they give birth to reduce excessive blood flow.

As the researchers and the communities dwelled through the Bush the community roles were also very prominent although not communicated explicitly. The father is responsible for identifying the food to be dug out of the soil. The mother is the one that actually sits flat on the soil and start the digging process, while the little girl continue to dig much deeper into the soil. It is very important to take caution when digging up food from the soil, as dangerous insects such as scorpions might bite you. However for this communities this seems not to be a major concern, as they will again use some of the veld trees or plants to extract the poison from the victim. It was also very interesting to the authors that the San people of Tsumkwe also have their very own version of 'All you need is love'. This fairy-tale story is illustrated by Figure 10. It shows that love is universal and all humans need love, affection and care.

The primary objectives that this paper intended to achieve was to help policy and decision makers in terms of the guidance and assistance they need to ask from San people instead of making very crucial decision which could impact their livelihoods. In addition not taking into account those in minority, does not make policy makers any different from colonial masters. It has come to light from this study that when entrepreneurship is viewed from the vantage point of indigenous people such as the San currently under study it can indeed alleviate poverty and also business involvement and continued interest on a national level amongst the communities. The San people mostly trade in the Bazaar economy with no formal transactions and no medium of monetary exchange. This study shed more light to the fact that indigenous entrepreneurship has both economic and non-economic objectives. These communities are indeed doing amazing things with limited resources.

\section{Conclusions and recommendations for further research}

This paper explored the role of culture and entrepreneurship of the San people in the Republic of Namibia, with reference to the Tsumkwe village. The study indeed found 
that the San people use culture and entrepreneurship, for community development for the development of the Namibian economy. They achieve this by becoming adaptive and coping with their daily living conditions and situations. From the fieldwork it is without a doubt evident that the San people indeed sanctify their daily experiences. For example there are very clear and distinctive roles in a family or the community. The man walks in ahead of everyone else in the bush and he also is the figurehead of the family. The women should just be behind and she has to ensure that the food or medicine required for the house is collected, while the children act as the immediate helping hand to the mother. This clearly indicates the role of culture and entrepreneurship within the daily livelihoods of the community. The economic and non-economic objectives of indigenous entrepreneurship were clear from this study.

Through the fieldwork of this paper it is evident that these communities practice indigenous entrepreneurship, which is the ability of communities to use their local resources at hand to achieve self-reliance and self-determination. The daily living conditions of the San people is not necessarily supported by technology or the latest apps, but things get done, as communities are fed, some children managed to go to school, communities are able to design their own jewellery and necklaces from the roots of trees or plants. This takes tremendous deliberate conscious effort, but with the San people, it is indeed clear that where there is a willing power, persistence, perseverance and patience it can be done. Most of the people interviewed for this paper felt that development is normally not viewed from their vantage point, but from what the western world view as development.

The findings of this paper reveal that an entrepreneurial culture is very important to the San people, as it makes them who they are. It shapes their behaviour, attitude, and thinking and how they view the world from their perspective. It also became clear to the authors that the communities are willing to take an active role in the developmental goals and objectives of Namibia, given that they are not forced to lose their cultural values and belief systems.

Given the above mentioned the researchers' further recommends that the role that the San people can play in the overall development of the country can be enhanced through formalised education, in-service training, skills development and awareness programmes. The Namibian government should make a deliberate effort to visit these communities, and support in whatever way they can. The government should prioritise bringing development to these communities, as these people are in dire need of physical and monetary resources, and are also in need of help as to how they can bridge the technological gap. Policy makers have to really find ways that policies must be implemented in ensuring that rural poor breaks out of the poverty cycle. There must be more action than words. For example how can we help the San people in marketing their trees and plants which can be used for medical purposes. Researchers and communities from regions who have active entrepreneurial ventures can co-partner with the San people of Tsumkwe. They can seek solutions together relating to the development of individuals and society in general.

The paper therefore concludes that the San people of Tsumkwe village can actively contribute to the economic advancement and development of Namibia, with their unique entrepreneurial culture. The role and the place of the San people in development can only grow through active participation in the Namibian markets, cultural or traditional festivals, business forums and trade fairs. It is thus the assertion of the researchers that 
being part of the decision making process and truly telling Namibia and the world what is uniquely theirs will enable the San people not only to break through the cycle of poverty that meets the eye, but also the cycle of poverty which is in the mind.

\section{References}

April, W.I. (2010) 'Reflecting upon the entrepreneurship initiatives in new emerging nations: zooming the cultural lens on education systems in two former German colonies', World Review of Entrepreneurship, Management and Sustainable Development, Vol. 6, No. 3, pp.163-174.

April, W.I., Itenge, D.I., Van der Westhuizen, J.P. and Emvula, L.S. (2017) 'Empowering Namibian indigenous people through entrepreneurship: the case from the Nama people, indigenous people', in Venkatesan, P. (Ed.): InTech, DOI: 10.5772/intechopen.69886 [online] https://www.intechopen.com/books/indigenous-people/empowering-namibian-indigenouspeople-through-entrepreneurship-the-case-from-the-nama-people.

Barnes, J. (2000) Can Non-Aboriginal People Represent Aboriginal Peoples? Past Imperfect Undergraduate History Journal University of Sydney 1999-2000, The University of Sydney, Sydney.

Bhensdadia, R.R. and Dana, L.P. (2004) 'Globalisation and rural poverty', International Journal of Entrepreneurship and Innovation Management, Vol. 4, No. 5, pp.458-468.

Bygrave, W. and Zacharakis, A. (2011) Entrepreneurship, 2nd ed., USA.

Dana, L.P. (1995) 'Entrepreneurship in a remote sub-Artic community: Nome, Alaska', Entrepreneurship: Theory and Practice, Fall, Vol. 20, No. 1, pp.55-72, Reprinted in Krueger, N. (2002) Entrepreneurship, Innovation and Change, December, Vol. 4, No. 4, pp.347-358.

Dana, L.P. (1996) 'Self-employment in the Canadian sub-Artic: an exploratory study', Canadian Journal of Administrative Studies, Vol. 13, No. 1, pp.65-77.

Dana, L.P. (2000) Economies of the Eastern Mediterranean Region: Economic Miracles' in the Making, World Scientific, Singapore, London and Hong Kong.

Dana, L.P. (2007) 'Promoting SMEs in Africa: some insights from an experiment in Ghana and Togo', Journal of African Business, Vol. 8, No. 2, pp.151-174.

Dana, L.P. (2015) 'Indigenous entrepreneurship: an emerging field of research', Int. J. Business and Globalisation, Vol. 14, No. 2, pp.158-166.

Desai, V. (1999) Dynamics of Entrepreneurial Development and Management, 3rd ed., Himalaya Publishing House, Mumbai.

Hindle, K. and Lansdowne, M. (2005) 'Spirits on new paths: towards a globally relevant paradigm of indigenous entrepreneurship research', Journal of Small Business and Entrepreneurship, Spring, Vol. 18, No. 2, pp.131-142.

Kumar, R. (2014) Research Methodology: A Step by Step Guide for Beginners, 4th ed., Asford Color Press, London.

Mbigi, L. (2005) The Spirit of African Leadership, Knowres Publishing, South Africa.

Peredo, A.M., Anderson, R.B., Galbraith, C.S., Honig, B. and Dana, L.P. (2004) 'Towards a theory of indigenous entrepreneurship', International Journal of Entrepreneurship and Small Business, Vol. 1, Nos. 1/1, pp.2-17.

Schumpeter, J.A. (1934) Theory of Economic Development, Harvard University Press, Cambridge, Massachusetts.

Taylor, S.J. and Bogdan, R. (1998) Introduction to Qualitative Research Methods: A Guidebook and Resource, 3rd ed., Wiley, New York. 